\title{
Production Potential of Summer Greengram [Vigna radiata (L) wilczek] to Different Nutrient Management Practices under South Gujarat Condition
}

\author{
V. M. Patel ${ }^{1}$, K. A. Shah ${ }^{2 *}$ and Prabhu Nayaka ${ }^{3}$ \\ ${ }^{1}$ Department of Agronomy, Navsari Agricultural University, \\ Eru Char Rasta, Navsari 396 450, Gujarat, India \\ ${ }^{2}$ Agronomy, Krishi Vigyan Kendra, Navsari Agricultural University, \\ Eru Char Rasta, Navsari 396 450, Gujarat, India \\ ${ }^{3}$ Plant Protection, Krishi Vigyan Kendra, Navsari Agricultural University, Eru Char Rasta, \\ Navsari 396 450, Gujarat, India \\ *Corresponding author
}

\section{Keywords \\ Greengram, Integrated nutriment management, Vermicompost, FYM, Enrich banana psuedostem sap}

\section{Article Info}

Accepted:

15 March 2020

Available Online:

10 April 2020

\section{A B S T R A C T}

A field experiment was conducted during summer season of 2018 at the college farm, Navsari Agricultural University, Navsari to study the "Production potential of summer greengram [Vigna radiata (L.) Wilczek] to different nutrient management practices under south Gujarat condition". The soil of the experimental field was clayey in texture having medium to poor drainage, low in available nitrogen and organic carbon and medium in available phosphorus and available potassium. Total seven treatments viz., Control $\left(\mathrm{T}_{1}\right)$, FYM @ 2.5 t/ha + 100\% RDF ( $\left.T_{2}\right)$, FYM @ 5 t/ha + 50\% RDF $\left(\mathrm{T}_{3}\right)$, FYM @ 2.5 t/ha + $50 \% \mathrm{RDF}+$ spraying of enrich banana psuedostem sap @ $10 \mathrm{ml} / \mathrm{l}$ of water at branching and $50 \%$ flowering stage $\left(\mathrm{T}_{4}\right)$, vermicompost @ $1 \mathrm{t} / \mathrm{ha}+100 \% \mathrm{RDF}\left(\mathrm{T}_{5}\right)$, vermicompost @ $2 \mathrm{t} / \mathrm{ha}+50 \% \mathrm{RDF}\left(\mathrm{T}_{6}\right)$ and vermicompost @ $1 \mathrm{t} / \mathrm{ha}+50 \% \mathrm{RDF}+$ spraying of enrich banana psuedostem sap @ $10 \mathrm{ml} / \mathrm{l}$ of water at branching and $50 \%$ flowering stage $\left(\mathrm{T}_{7}\right)$ were tested in randomized block design with four replications. Most of the growth and yield attributes viz., plant population at harvest, plant height at $60 \mathrm{DAS}$, test weight and harvest index did not affected significantly by different nutrient management treatments. An application of vermicompost @ 1 t/ha $+50 \%$ RDF + spraying of enrich banana psuedostem sap @ $10 \mathrm{ml} / \mathrm{l}$ of water at branching and $50 \%$ flowering stage $\left(\mathrm{T}_{7}\right)$ recorded significantly higher plant height $(47.41 \mathrm{~cm})$ at harvest, number of branches per plant (4.30), dry matter production per plant (10.71 g), number of pod per plant (32.75), number of seed per pod (9.30), seed yield (1390 kg/ha) and haulm yield (1751 kg/ha) over control. Similarly, the maximum gross realization Rs 95594/ha, net realization Rs 63645/ha and the BCR value of 2.99 were observed with the application of vermicompost @ $1 \mathrm{t} / \mathrm{ha}+50 \%$ $\mathrm{RDF}+$ spraying of enrich banana psuedostem sap @ $10 \mathrm{ml} / \mathrm{l}$ of water at branching and 50 $\%$ flowering stage. 


\section{Introduction}

Greengram [Vigna radiata (L.) Wilczek] is third important pulse crop after chickpea and pigeon pea, cultivated throughout India for its multipurpose uses as vegetable, pulse, fodder and green manure crop. In Gujarat, kharif and summer greengram was cultivated in an area of 129 ha with production 61 tonnes and yield $473 \mathrm{~kg} / \mathrm{ha}$ (Anonymous, 2016). It is a good source of protein (20-24\%), carbohydrates $(60-62 \%)$, water $(10 \%)$, fat $(1.0 \%)$, fiber $(4.0 \%)$ and ash $(3.0 \%)$. Greengram protein is deficient in methionine and cystein but rich in lysine making it an excellent compliment to rice. It is a good source of mineral, provitamin A, B complex and ascorbic acid. Besides being a rich source of protein, it maintains soil fertility through biological nitrogen fixation in soil and thus plays a vital role in furthering sustainable agriculture (Kannaiyan, 1999).

Green gram are known to improve the physical characteristics of soil through tap root system which opens the soil in to the deeper strata and their ability to use atmospheric nitrogen through biological nitrogen fixation which is economically sound and environmentally acceptable. In addition, it also provides nutritious fodder and feed for livestock. It is also drought resistant and prevents soil erosion due to their deep root and good ground covers, because of these good characters, pulses are called as "Marvel of Nature".

Due to low and unstable production and increasing the population pressure, per capita availability of pulses decreasing from $69 \mathrm{~g}$ in 1961 to about $31.6 \mathrm{~g}$ in 2010-11, against the minimum requirement of $80 \mathrm{~g}$ per capita per day (Anonymous, 2011). To make up minimum $50 \mathrm{~g}$ pulses per capita per day and further demand from burgeoning population at least $24 \mathrm{~m}$ tones tones of pulses are required in 2020-21 (Anonymous, 2016). To satisfy the demand of pulses requirement of ever increasing population, the production of pulses has to be increased only by increasing the yield/unit area/day.

There was continuously increasing in cost of chemical fertilizers in recent past has adversely affected the use of chemical fertilizers. Further, it is now realize that no single nutrient sources could fulfill the nutritional requirement of crop. Moreover, excess and indiscriminate use of synthetic agro-chemical has resulted in deterioration of natural resources by polluting crop environment leading to unsustainable productivity of land. In this regards, the integration of all sources viz., organic, inorganic and foliar nutrition is best possible way to satisfy the demand of crop to improve the productivity and sustains the soil health and environmental safety.

Various sources of organic manures are major source of all the essential plant element nutrients which enhances the soil fertility and crop productivity. The use of farm yard manure (FYM)/vermicompost along with inorganic fertilizer increases the nutrient use efficiency and also improves the physical properties of soil. FYM helps to buffer soils against rapid chemical changes. FYM also acts as a source of energy for the growth of soil microbes. It improves physio-chemical properties of soil such as aggregation, aeration, permeability, water holding capacity, slow release of nutrients, increase in cation exchange capacity, stimulation of soil flora and fauna etc. Vermicompost is an aerobically degraded organic matter which has undergone chemical disintegration by the enzymatic activity in the guts of worms and also enzymes of the associated microbial population. It contains 0.80 to $1.10 \% \mathrm{~N}, 0.40$ to $0.80 \% \mathrm{P}_{2} \mathrm{O}_{5}$ and 0.80 to $0.98 \% \mathrm{~K}_{2} \mathrm{O}, 10$ to $52 \mathrm{ppm} \mathrm{Cu}, 186.60$ ppm Zn, 930.00 ppm Fe 
and plant growth promoting substances such as NAA, cytokinins, gibberellins etc. (Giraddi et al., 2006).

The foliar applied nutrients are also more effective as compared to soil applied nutrients. Because of higher uptake efficiency, foliar supply of nutrients can increase photosynthetic efficiency by delaying the onset of leaf senescence (Yadav and Choudhary, 2012).

Hence, adoption of appropriate nutrients management strategies holds a great potential in boosting the greengram yield. Therefore, integrated nutrient management is crucial not only for the increasing the yield, but also for the improvement of soil health. Considering the above facts and very less work done in south Gujarat region the experiment has been planned to study the "Production potential of summer greengram [Vigna radiata (L.) Wilczek] to different nutrient management practices under south Gujarat condition”.

\section{Materials and Methods}

A field experiment was conducted during summer season of 2018 at the college farm, Navsari Agricultural University, Navsari, Gujarat. The soil of the experimental field was clayey in texture having medium to poor drainage, EC (0.55 dS/m) and $\mathrm{pH}(8.10)$, low in available nitrogen $(180.30 \mathrm{~kg} / \mathrm{ha})$ and organic carbon $(0.30 \%)$ and medium in available phosphorus (38.30 $\mathrm{kg} / \mathrm{ha})$ and available potassium $(270.50 \mathrm{~kg} / \mathrm{ha})$ were determined by Kjeldahl's method, Olsen's method and Flame photometric method, respectively. Total seven treatments viz., Control $\left(\mathrm{T}_{1}\right)$, FYM @ $2.5 \mathrm{t} / \mathrm{ha}+100 \% \mathrm{RDF}$ $\left(\mathrm{T}_{2}\right), \mathrm{FYM} @ 5 \mathrm{t} / \mathrm{ha}+50 \% \mathrm{RDF}\left(\mathrm{T}_{3}\right), \mathrm{FYM}$ @ $2.5 \mathrm{t} / \mathrm{ha}+50 \% \mathrm{RDF}+$ spraying of enrich banana psuedostem sap @ $10 \mathrm{ml} / \mathrm{l}$ of water at branching and $50 \%$ flowering stage $\left(\mathrm{T}_{4}\right)$, vermicompost @ 1 t/ha $+100 \% \operatorname{RDF}\left(\mathrm{T}_{5}\right)$, vermicompost @ 2 t/ha + 50\% RDF $\left(\mathrm{T}_{6}\right)$ and vermicompost @ 1 t/ha + 50\% RDF + spraying of enrich banana psuedostem sap @ $10 \mathrm{ml} / \mathrm{l}$ of water at branching and $50 \%$ flowering stage $\left(\mathrm{T}_{7}\right)$ were tested in randomized block design with four replications. Greengram variety "GM-6" seeds were sown at $30 \mathrm{~cm} \times 10 \mathrm{~cm}$ spacing. Farm yard manure and vermicompost were incorporated about 15 days before sowing in soil as per treatments. The entire dose of nitrogen and phosphorus as per treatments applied at basal application just before sowing and spraying of enriched banana pseudostem sap were applied as per the treatments. Enriched banana pseudostem sap is first time prepared and patented by Navsari Agricultural University, Navsari which was developed by team of National Innovative Project on "A Value Chain on Utilization of Banana Pseudostem for fiber and Other Value Added Products." This enriched sap is a very good source of essential plant nutrients namely $\mathrm{N}$ (70.0 mg/l), P (26.1mg/l), K (170 mg/l), Fe (7.44 mg/l), Mn (2.66 mg/l), Zn (0.40 mg/l) $\mathrm{Cu}(0.26 \mathrm{mg} / \mathrm{l})$ etc as well as hormones $\mathrm{GA}_{3}$ and Cytokinin. Urea and di- ammonium phosphate were taken as fertilizer sources for $\mathrm{N}$ and $\mathrm{P}$, respectively. All other operation was performed as per recommendations of the crops. The data on seed and haulm yields as well as protein content were recorded under various treatments after harvest of crop. The results were analysis statistically to draw suitable interference as per the standard ANOVA techniques suggested by Gomez and Gomez (1984).

\section{Results and Discussion}

\section{Growth attributes}

The difference in plant population at harvest was found to be non significant due to the application of different treatments. However, numerically higher plant population at harvest 
was recorded with $\mathrm{T}_{6}$ (vermicompost @ $2 \mathrm{t} / \mathrm{ha}$ $+50 \%$ RDF). Thus, whatever variation observed in the investigation is likely attributed to different treatments applied in the experiment (Table 1).

The variation in plant height of greengram due to different nutrient management treatments were found to be non significant at 60 DAS. However, it was significantly influenced by different treatment at harvest. Significantly the taller plant height at harvest $(47.41 \mathrm{~cm})$ was registered with the application of $\mathrm{T}_{7}$ (vermicompost @ $1 \mathrm{t} / \mathrm{ha}+50 \% \mathrm{RDF}+$ spraying of enrich banana psuedostem sap @ $10 \mathrm{ml} /$ litre of water at branching and $50 \%$ flowering stage) over control, which was at par with application of vermicompost @ 2 t/ha + 50\% RDF ( $\left.\mathrm{T}_{6}: 43.67 \mathrm{~cm}\right), \mathrm{FYM} @ 2.5$ $\mathrm{t} / \mathrm{ha}+50 \% \mathrm{RDF}+$ spraying of enrich banana psuedostem sap @ $10 \mathrm{ml} /$ litre of water at branching and 50\% flowering stage $\left(\mathrm{T}_{4}: 43.74\right.$ $\mathrm{cm})$ and FYM @ $2.5 \mathrm{t} / \mathrm{ha}+100 \% \mathrm{RDF}\left(\mathrm{T}_{2}\right.$ : $43.29 \mathrm{~cm})$. Non significantly, but numerically higher plant height at 60 DAS was also observed under the same treatment $\mathrm{T}_{7}$, which was closely followed by the treatment $\mathrm{T}_{4}$. The lowest plant height at harvest $(38.76 \mathrm{~cm})$ was recorded under control. The percentage increase in the plant height at harvest of 22.31, 12.84 and 12.66 per cent under the treatment $\mathrm{T}_{7}, \mathrm{~T}_{4}$ and $\mathrm{T}_{6}$ over control respectively. Increased in plant height under the different nutrient management practices might be due to two reason, firstly addition of either FYM or vermicompost along with in organic fertilizers in to soil improved physical, chemical and biological properties of soil and this leads to improve the root growth and development and thereby uptake of nutrients and water from greater soil volume resulting in to better plant growth and secondly foliar application of nutrients at a critical crop growth stage (branching and flowering) helps in regulating the cell division and multiplication as well as cell elongation and development of leaves and other plant's part. It also helps in enhance the synthesis of carbohydrates and protein in plants and ultimately the photosynthetic activity resulting in better development of plant growth. Similar results are in accordance with the findings of Rathod and Gawande (2012), Jat et al., (2012), Gorade et al., (2014), Elamin and Madhavi (2015) and Armin et al., (2016) with respect to plant height.

An application of vermicompost @ 1 t/ha + $50 \%$ RDF + spraying of enrich banana pseudostem sap @ $10 \mathrm{ml} /$ litre of water at branching and $50 \%$ flowering stage $\left(\mathrm{T}_{7}\right)$ produced significantly higher number of branches per plant (4.30) over rest of the treatments, except the control and FYM @ $2.5 \mathrm{t} / \mathrm{ha}+100 \%$ RDF. Significantly the lowest number of branches per plant (2.75) was found under the control treatment. An application of vermicompost @ $1 \mathrm{t} / \mathrm{ha}+50 \%$ $\mathrm{RDF}+$ spraying of enrich banana psuedostem sap@ $10 \mathrm{ml} /$ litre of water at branching and $50 \%$ flowering stage $\left(\mathrm{T}_{7}\right)$ gave significantly higher number of branches per plant (4.30) over control, which was remain at par with vermicompost @ 2 t/ha + 50\% RDF ( $\mathrm{T}_{6}$ : 4.10), vermicompost @ 1 t/ha + 100\% RDF $\left(\mathrm{T}_{5}: 3.75\right), \mathrm{FYM} @ 2.5 \mathrm{t} / \mathrm{ha}+50 \% \mathrm{RDF}+$ spraying of enrich banana psuedostem sap @ $10 \mathrm{ml} /$ litre of water at branching and 50\% flowering stage $\left(\mathrm{T}_{4}: 3.95\right)$ and FYM @ 5 t/ha $+50 \%$ RDF ( $\left.\mathrm{T}_{3}: 3.70\right)$. This could be attributed due to favourable effect of combined application of organic and inorganic fertilizers added in to the soil helps in improvement of physico-chemical properties of soil and assures the quick and easy availability of essential plant nutrients resulted in better crop growth in terms of number of branches per plant. These findings are substantiated with those reported by Jat et al., (2012), Kumar et al., (2015), Misal et al., (2015) and Armin et al., (2016). 
Dry matter production per plant was significantly affected by different nutrient management treatments application. Significantly the lowest dry matter production (8.06 g) was observed in control, where as the highest dry matter production (10.71 g) was recorded with the application of vermicompost @ 1 t/ha + 50\% RDF + spraying of enrich banana psuedostem sap @ $10 \mathrm{ml} /$ litre of water at branching and $50 \%$ flowering stage. It might be due to the cumulative effect of an increased availability of nutrients with application of chemical and organic fertilizers along with the foliar spray at critical crop growth stage helps in solubilization of native and applied nutrients available to roots and growth promoting substances like $\mathrm{GA}_{3}$ and cytokinin to plant, which might have increased growth parameters and ultimately the total biomass yield of greengram. The present findings are within the close vicinity of those reported by Patel et al., (2010), Jat et al., (2012) and Kumar et al., (2015).

\section{Yield attributes}

The variation in the yield attributing parameters viz., number of pods per plant and number of seeds per pod were remarkably influenced by different nutrient management treatments. Vermicompost @ 1 t/ha + 50\% $\mathrm{RDF}+$ spraying of enrich banana psuedostem sap@ $10 \mathrm{ml} /$ litre of water at branching and $50 \%$ flowering stage $\left(\mathrm{T}_{7}\right)$ was observed remarkably the highest number of pods per plant (32.75) and number of seed per pod (9.30), but it was found at par with remaining all other treatments, except the control. Significantly lowest pods per plant (25.70) and number of seed per pod (7.20) registered with control. Treatment $\mathrm{T}_{7}$ and $\mathrm{T}_{4}$ increases the 27.43 and 24.51 as well as 30.98 and 28.87 per cent higher number of pods per plant and number of seeds per pod over control, respectively. Different nutrient management treatments did not exert their significant influence on test weight of greengram. However, the numerically higher value of test weight (42.92 g) was observed under the application of FYM @ $2.5 \mathrm{t} / \mathrm{ha}+$ $50 \%$ RDF + spraying of enrich banana psuedostem sap @ $10 \mathrm{ml} /$ litre of water at branching and $50 \%$ flowering stage followed by $42.70 \mathrm{~g}$ in treatment $\mathrm{T}_{7}$. Increasing in the yield attributes may be due to the fact that farmyard manure or vermicompost increase the adsorptive power of soil for cation and anion and these absorbed ions are released slowly for the entire crop growth period resulted in better nutrient availability at active crop growth. Secondly, integrated use of organic, inorganic and foliar spray of nutrients at a critical crop growth stages resulted in better growth of plants associated with increased availability of nutrients might have resulted in greater translocation of photosynthates from source to sink site that favourably influenced flowering, fruiting and ultimately resulted into increased number of pods per plant and number of seeds per pod. Positive responses in terms of yield attributes reported by Sharma et al., (2012), Elamin and Madhavi (2015), Armin et al., (2016), Prajapati et al., (2016) Akhila et al., (2017) and Singh et al., (2017).

\section{Seed and haulm yield}

The different nutrient management treatments showed significant differences on seed and haulm yields of greengram. An application of vermicompost @ 1 t/ha + 50\% RDF + spraying of enrich banana psuedostem sap @ $10 \mathrm{ml} /$ litre of water at branching and 50\% flowering stage was produced significantly the highest seed $(1390 \mathrm{~kg} / \mathrm{ha})$ and haulm yields $(1751 \mathrm{~kg} / \mathrm{ha})$ over the rest of the treatments, except control. The lowest seed yield (658 kg/ha) and haulm yield (1045 $\mathrm{kg} / \mathrm{ha}$ ) of greengram registered under control. There were 111.25 and 108.03 per cent seed 
yield and 67.55 and 67.27 per cent haulm yield increased under the treatment $\mathrm{T}_{7}$ and $\mathrm{T}_{4}$ over the control, respectively. The increase in seed yield with application of different nutrient management treatments was mainly due to cumulative effect of significant increased in the growth and yield attributing component like number of branches, number of pods per plant and number of seeds per pod. Similarly, the haulm yield was remarkably increased due to the significant improvement in the growth attributing characters viz., plant height, number of branches per plant and dry matter production per plant. The similar types of results were supported by the findings of Dhasora and Solanki (2010), Chaudhary and Yadav (2011), Jat et al., (2012), Vitnor et al., (2015), Prajapati et al., (2016), Dekhane et al., (2017), Singh et al., (2017), and Kalariya et al., (2018).

An application of different nutrient management treatments failed to show any significant effect on harvest index (Table 2). However, a numerically higher value of harvest index was found under the application of vermicompost @ $2 \mathrm{t} / \mathrm{ha}+50 \% \mathrm{RDF}\left(\mathrm{T}_{6}\right.$ : $44.78 \%)$. These results corroborated the findings of Rathod and Gawande (2012).

Table.1 Effect of different nutrient management practices on growth attributes of summer greengram

\begin{tabular}{|c|c|c|c|c|c|}
\hline \multirow[t]{2}{*}{ Treatment } & \multirow{2}{*}{$\begin{array}{c}\text { Plant } \\
\text { population } \\
\text { at harvest } \\
\text { (per sq. m.) }\end{array}$} & \multicolumn{2}{|c|}{$\begin{array}{l}\text { Plant height } \\
(\mathbf{c m})\end{array}$} & \multirow{2}{*}{$\begin{array}{c}\text { Number of } \\
\text { branches } \\
\text { per plant at } \\
\text { harvest }\end{array}$} & \multirow{2}{*}{$\begin{array}{c}\text { Dry matter } \\
\text { production at } \\
\text { harvest } \\
\text { (g/ plant ) }\end{array}$} \\
\hline & & $\begin{array}{c}60 \\
\text { DAS }\end{array}$ & $\begin{array}{c}\text { at } \\
\text { harvest }\end{array}$ & & \\
\hline$T_{1}$ : Control & 27.05 & 33.57 & 38.76 & 2.75 & 8.06 \\
\hline$T_{2}:$ FYM @ 2.5 t/ha + 100\% RDF & 27.50 & 35.19 & 43.29 & 3.60 & 10.00 \\
\hline$T_{3}:$ FYM @ 5 t/ha + 50\% RDF & 28.00 & 35.41 & 42.77 & 3.70 & 10.12 \\
\hline $\begin{array}{l}\mathrm{T}_{4}: \text { FYM @ } 2.5 \mathrm{t} / \mathrm{ha}+50 \% \mathrm{RDF}+ \\
\text { spraying of EBPS @ } 10 \mathrm{ml} / \mathrm{l} \text { of } \\
\text { water at branching and } 50 \% \\
\text { flowering stage. }\end{array}$ & 28.40 & 36.20 & 43.74 & 3.95 & 10.48 \\
\hline $\begin{array}{l}\mathrm{T}_{5} \text { : Vermicompost @ } 1 \mathrm{t} / \mathrm{ha}+100 \% \\
\text { RDF }\end{array}$ & 28.30 & 34.90 & 42.46 & 3.75 & 10.06 \\
\hline $\begin{array}{l}T_{6}: \text { Vermicompost @ } 2 \text { t/ha + 50\% } \\
\text { RDF }\end{array}$ & 28.43 & 35.36 & 43.67 & 4.10 & 10.35 \\
\hline $\begin{aligned} \mathrm{T}_{7}: & \text { Vermicompost @ } 1 \mathrm{t} / \mathrm{ha}+50 \% \mathrm{RDF} \\
& + \text { spraying of EBPS @ } 10 \mathrm{ml} / \mathrm{l} \text { of } \\
& \text { water at branching and } 50 \% \\
& \text { flowering stage. }\end{aligned}$ & 28.28 & 38.45 & 47.41 & 4.30 & 10.71 \\
\hline S. Em. \pm & 0.66 & 1.43 & 1.54 & 0.22 & 0.48 \\
\hline $\mathrm{CD}(\mathrm{P}=\mathbf{0 . 0 5})$ & NS & NS & 4.58 & 0.67 & 1.44 \\
\hline CV \% & 4.71 & 8.06 & 7.51 & 11.99 & 9.70 \\
\hline
\end{tabular}


Table.2 Effect of different nutrient management practices on yield attributes, yield and harvest index of greengram

\begin{tabular}{|c|c|c|c|c|c|c|}
\hline Treatment & $\begin{array}{l}\text { Number of } \\
\text { pods per } \\
\text { plant }\end{array}$ & $\begin{array}{l}\text { Number } \\
\text { of seeds } \\
\text { per pod }\end{array}$ & $\begin{array}{l}\text { Test } \\
\text { weight } \\
\text { (g) }\end{array}$ & $\begin{array}{l}\text { Seed } \\
\text { yield } \\
\text { (kg/ha) }\end{array}$ & $\begin{array}{l}\text { Haulm } \\
\text { yield } \\
\text { (kg/ha) }\end{array}$ & $\begin{array}{l}\text { Harvest } \\
\text { index } \\
(\%)\end{array}$ \\
\hline $\mathbf{T}_{1}:$ Control & 25.70 & 7.10 & 39.02 & 658 & 1045 & 38.88 \\
\hline $\mathrm{T}_{2}:$ FYM @ $2.5 \mathrm{t} / \mathrm{ha}+100 \% \mathrm{RDF}$ & 29.60 & 8.25 & 41.12 & 1218 & 1588 & 43.41 \\
\hline $\mathrm{T}_{3}:$ FYM @ 5 t/ha + 50\% RDF & 30.70 & 8.30 & 42.12 & 1285 & 1600 & 44.58 \\
\hline $\begin{aligned} \mathrm{T}_{4}: & \mathrm{FYM} @ 2.5 \mathrm{t} / \mathrm{ha}+50 \% \mathrm{RDF}+ \\
& \text { spraying of EBPS @ } 10 \mathrm{ml} / \mathrm{l} \text { of water } \\
& \text { at branching and } 50 \% \text { flowering } \\
& \text { stage. }\end{aligned}$ & 32.00 & 9.15 & 42.92 & 1369 & 1748 & 43.92 \\
\hline $\mathrm{T}_{5}:$ Vermicompost @ $1 \mathrm{t} / \mathrm{ha}+100 \% \mathrm{RDF}$ & 29.75 & 8.35 & 41.60 & 1215 & 1562 & 43.66 \\
\hline $\mathrm{T}_{6}:$ Vermicompost @ 2 t/ha $+50 \%$ RDF & 30.90 & 8.40 & 41.94 & 1305 & 1603 & 44.78 \\
\hline $\begin{aligned} \mathrm{T}_{7}: & \text { Vermicompost @ } 1 \mathrm{t} / \mathrm{ha}+50 \% \mathrm{RDF} \\
& + \text { spraying of EBPS @ } 10 \mathrm{ml} / \mathrm{l} \text { of } \\
& \text { water at branching and } 50 \% \\
& \text { flowering stage. }\end{aligned}$ & 32.75 & 9.30 & 42.70 & 1390 & 1751 & 44.26 \\
\hline S. Em. \pm & 1.17 & 0.40 & 0.99 & 59.87 & 65.27 & 1.85 \\
\hline $\mathrm{CD}(\mathrm{P}=\mathbf{0 . 0 5})$ & 3.48 & 1.17 & NS & 177.88 & 193.92 & NS \\
\hline CV \% & 7.76 & 9.40 & 4.75 & 9.93 & 8.39 & 8.51 \\
\hline
\end{tabular}

Table.3 Effect of different nutrient management practices on economics of greengram

\begin{tabular}{|c|c|c|c|c|c|c|}
\hline \multirow[t]{2}{*}{ Treatment } & \multicolumn{2}{|c|}{ Yield (kg/ha) } & \multirow{2}{*}{$\begin{array}{l}\text { Gross } \\
\text { Return } \\
\text { (Rs/ha) }\end{array}$} & \multirow{2}{*}{$\begin{array}{l}\text { Cost of } \\
\text { Production } \\
\quad(\text { Rs/ha) }\end{array}$} & \multirow{2}{*}{$\begin{array}{c}\text { Net } \\
\text { Return } \\
\text { (Rs/ha) }\end{array}$} & \multirow[t]{2}{*}{ BCR } \\
\hline & Seed & Haulm & & & & \\
\hline $\mathbf{T}_{1}:$ Control & 658 & 1045 & 45884 & 22864 & 23020 & 2.01 \\
\hline$T_{2}:$ FYM @ 2.5 t/ha + 100\% RDF & 1218 & 1588 & 83931 & 30701 & 53230 & 2.73 \\
\hline $\mathrm{T}_{3}:$ FYM @ 5 t/ha + 50\% RDF & 1285 & 1600 & 88322 & 34832 & 53490 & 2.54 \\
\hline $\begin{array}{c}\mathrm{T}_{4}: \text { FYM @ } 2.5 \mathrm{t} / \mathrm{ha}+50 \% \mathrm{RDF}+\text { spraying } \\
\text { of EBPS @ } 10 \mathrm{ml} / \mathrm{l} \text { of water at } \\
\text { branching and } 50 \% \text { flowering stage. }\end{array}$ & 1369 & 1748 & 94260 & 31412 & 62848 & 3.00 \\
\hline $\begin{array}{l}T_{5}: \text { Vermicompost @ } 1 \text { t/ha }+100 \% \\
\text { RDF }\end{array}$ & 1215 & 1562 & 83663 & 31237 & 52426 & 2.68 \\
\hline $\begin{array}{l}\text { T }_{6}: \text { Vermicompost @ } 2 \text { t/ha }+50 \% \\
\text { RDF }\end{array}$ & 1305 & 1603 & 89656 & 35905 & 53751 & 2.50 \\
\hline $\begin{array}{c}\mathrm{T}_{7}: \text { Vermicompost @ } 1 \mathrm{t} / \mathrm{ha}+50 \% \mathrm{RDF}+ \\
\text { spraying of EBPS @ } 10 \mathrm{ml} / \mathrm{l} \text { of water at } \\
\text { branching and } 50 \% \text { flowering stage. }\end{array}$ & 1390 & 1751 & 95594 & 31949 & 63645 & 2.99 \\
\hline S. Em. \pm & 59.87 & 65.27 & - & - & - & - \\
\hline $\mathrm{CD}(\mathbf{P}=\mathbf{0 . 0 5})$ & 177.88 & 193.92 & - & - & - & - \\
\hline $\mathrm{CV} \%$ & 9.93 & 8.39 & - & - & - & - \\
\hline
\end{tabular}




\section{Economics}

The data presented in Table 3 revealed that the application of vermicompost @ 1 t/ha + $50 \%$ RDF + spraying of enrich banana pseudostem sap @ $10 \mathrm{ml} /$ litre of water at branching and 50\% flowering stage incurve maximum gross realization (95594 ₹ /ha), net realization (63645 ₹/ha) and BCR (2.99), which was closely followed by the treatment FYM @ $2.5 \mathrm{t} / \mathrm{ha}+50 \% \mathrm{RDF}+$ spraying of enrich banana pseudostem sap @10 ml/liter of water at branching and $50 \%$ flowering stage record gross realization of 94260 ₹ /ha, net realization 62848 ₹/ha and $\mathrm{BC}$ ratio of 3.00. The lowest gross realization of ₹ 45884 $\mathrm{ha}^{-1}$, net realization of ₹ $23020 /$ ha and BCR of 2.01 was obtained under the control treatment. The increase in net returns might be due to higher seed yield obtained under this treatment as compared to cost involved under the same treatment. Similar views in direction of present finding were also expressed by Dashora and Solanki (2010), Patel et al., (2010), Jat et al., (2012), Sharma et al., (2012), Kumar et al., (2013), Akhila et al., (2017) and Meena et al., (2017).

Conclusion of the study is as follows:

From the results, it can be evident that an application of either FYM @ 2.5 t/ha or vermicompost @ 1 t/ha + 50\% RDF + spraying of enrich banana pseudostem sap @ $10 \mathrm{ml} / \mathrm{l}$ of water at branching and $50 \%$ flowering stage improved the plant height, number of branches per plant, number of pods per plant, number of seeds per pods, seed and haulm yield as well as protein content and would be useful to enhance the productivity of summer grenngram. Integrated use of organic, inorganic and foliar spray of enrich banana pseudostem sap may be suggested for the higher yield and quality along with overall betterment of summer greengram production.

\section{References}

Akhila, K., Kaswala, A. R., Priyanka. and Dubey, P. K. 2017. Effect of liquid fertilizers on growth yield and economics of the green gram (Vigna radiata) crop under organic farming. International Journal of Chemical Studies, 5(6): 809-812.

Anonymous 2011. Directorate of Agriculture, Gujarat state, Krushibhavan, Gandhinagar

Anonynous 2016. Ministry of Agriculture and Farmers welfare, Government of India.

Armin, W., Ashraf-Uz-Zaman, K. H., Zamil, S. S., Rabin, M. H., Bhadra, A. K. and Khatun, F. 2016. Combined effect of organic and inorganic fertilizers on the growth and yield of mungbean (bari mung 6). International Journal of Scientific and Research Publications, 6(7): 557-561.

Choudhary, G. L. and Yadav, L. R. 2011. Effect of fertility levels and foliar nutrition on cowpea productivity. Journal of Food Legumes, 24(1): 67-68.

Dashora, L. N. and Solanki, N. S. 2010. Effect of integrated nutrient management on productivity of urdbean under rainfed conditions. Journal of Food Legumes, 23(3\&4): 249-250.

Dekhane, S. S., Mangave, B. D., Dumbre, R. B. and Patel, D. J. 2017. Response of nutrient management practices through organic substances on rice var. GR-11 in north konkan coastal zone of Maharashtra. International Journal of Environment, Agriculture and Biotechnology, 2(6): 3007-3009.

Elamin, A. Y. and Madhavi, K. 2015. Residual effect of integrated nutrient management on growth and yield parameters of rabi chickpea (Cicer arietinum L.) under cropping system. American Journal of Scientific and Industrial Research, 6(5): 103-109. 
Giraddi, R. S., Babalad, H. B. and Chandaragi, D. M. 2006. Vermicompost technology. Technical Bulatin, University of Agriculture Sciences, Dharwad and DBT, New Delhi. pp: 1-6.

Gomez K. A. and Gomez A. A. 1984. Statistical Procedure for Agricultural Research. John Wiley and Sons, New York, pp: 139-264.

Gorade, V. N., Chavan, L. S., Jagtap, D. N. and Kolekar, A. B. 2014. Response of greengram (Vigna Radiata L.) varieties to integrated nutrient management in summer season. Agriculture Science Digest, 34(1): 36-40.

Jat, S. L., Prasad, K. and Parihar, C. M. 2012. Effect of organic manuring on productivity and economics of summer mungbean (Vigna radiate L.). Annals of Agricultural Research, 33(1\&2): 17-20.

Kalariya, V. D., Bhanderi, D. R., Patel, N. K. and Vaghasiya, J. M. 2018. Effect of foliar application of micronutrients, novel organic liquid fertilizer and sea weed extract on yield of okra [Abelmoschus esculentus L. (Moench)]. International Journal of Chemical Studies, 6(3): 1834-1836.

Kannaiyan S. 1999. Bioresource technology for sustainable agriculture. Associated Publishing Company. New Delhi, pp. 422.

Kumar, C. V., Vaiyapuri, K., Amanullah, M. and Gopalaswamy, G. 2013. Influence of foliar spray of nutrients on yield and economics of soybean (Glycine max L. Merill). Journal of Biological Sciences, 13: 563-565.

Kumar, D., Arvadiya, L. K., Usadadiya, V. P., and Patel, A. M. 2015. Growth and yield of chickpea (Cicer arietinum L.) as influenced by graded levels of fertilizers and bio-fertilizers. The Bioscan, 10(1): 335-338.

Meena, D., Bhushan, C., Shukla, A., Chaudhary, S. and Meena, S. S. 2017.
Effect of foliar application of nutrients on biological yield and economics urdbean (Vigna mungo (L.) Hepper). International Journal of Current Microbiology and Applied Sciences, 6(5): 2658-2662.

Misal, N. B., Patil, R. G., Shirgire, S. T. and Kulkarni, M. V. 2015. Effect of growing conditions and fertilizer scheduling with and without application of banana pseudostem sap (enriched) on biomass yield of fenugreek. Ecology, Environment \& Conservation, 21 (Suppl.): 351-356.

Patel, C. S., Patel, J. B., Suthar, J. V. and Patel, P. M. 2010. Effect of integrated nutrient management of clusterbean [Cyamopsis tetragonoloba (L.) Taub.] seed production cv. Pusa Navbahar. International Journal of Agricultural Sciences, 6(1): 206-208.

Prajapati, S. K., Tyagi, P. K., Chourasia, S. K. and Upadhyay, A. K. 2016. Effect of integrated nutrient management practices on growth and yield of summer mungbean (Vigna radiata L.). A Journal of Multidisciplinary Advance Research, 5(1): 102-107.

Rathod, S. L. and Gawande, M. B. 2012. Response of greengram varieties to different fertilizer grades. International Journal of Science and Research, 3(7): 1313-1315.

Sharma, A., Rathod, P. S., Dharmaraj, P. S. and Chavan, M. 2012. Response of pigeonpea to biofertilizers in pigeonpea based intercropping systems under rainfed conditions. Karnataka Journal of Agricultural Sciences, 25(3): 322325.

Singh, M., Deokaran, M. J. S. and Bhatt, B. P. 2017. Effect of integrated nutrient management on production potential and quality of summer mungbean (Vigna radiata L.). Journal of Krishi Vigyan, 5: 39-45. 
Vitnor, S., Lal, E. P. and Rao, K. P. 2015. Studies on integrated nutrient management on seed yield and quality of greengram (Vigna radiate L.). International Journal of Recent Research in Life Sciences, 2(2): 42-45.
Yadav, L. R. and Choudhary, G. L. 2012. Effect of fertility levels and foliar nutrition on profitability, nutrient content and uptake of cowpea (Vigna unguiculata L. walp). Legume Research, 35(3): 258-260.

\section{How to cite this article:}

Patel, V. M., K. A. Shah and Prabhu Nayaka. 2020. Production Potential of Summer Greengram [Vigna radiata (L) wilczek] to Different Nutrient Management Practices under South Gujarat Condition. Int.J.Curr.Microbiol.App.Sci. 9(04): 1888-1897.

doi: https://doi.org/10.20546/ijcmas.2020.904.223 